\title{
Metabolic effects of feeding ethanol or propanol to postpartum transition Holstein cows
}

\author{
B. M. L. Raun and N. B. Kristensen ${ }^{1}$ \\ Department of Animal Health and Bioscience, Faculty of Agricultural Sciences, Aarhus University, DK-8830 Tjele, Denmark
}

\begin{abstract}
Eight lactating Holstein cows implanted with a ruminal cannula and permanent indwelling catheters in major splanchnic blood vessels were used to investigate metabolism of propanol and ethanol in the postpartum transition period. Cows were randomly allocated to 1 of 4 treatments in a randomized design with a 2 by 2 factorial arrangement of treatments. Factor 1 was $2.6 \mathrm{~g}$ of calcium carbonate $/ \mathrm{kg}$ of dry matter (DM) versus 1.5 $\mathrm{g}$ of 2-hydroxy-4-(methylthio)-butanoic acid isopropyl ester $/ \mathrm{kg}$ of DM. Factor 2 was supplementation with $14 \mathrm{~g}$ of propanol $/ \mathrm{kg}$ of DM (propanol treatment; PT) versus $14 \mathrm{~g}$ of ethanol $/ \mathrm{kg}$ of DM (ethanol treatment; ET). Only factor 2 data are presented in the present paper. Treatments were administered in silage-based total mixed rations and cows were fed the experimental total mixed ration from the day of parturition. Daily rations were fed in 3 equally sized portions at 8-h intervals. Eight hourly sets of ruminal fluid, arterial, and hepatic portal and hepatic vein samples were collected at day $-15 \pm 5,4,15$, and 29 relative to parturition. Dry matter intake and milk yield increased with days in milk (DIM), but were not affected by treatment. From prepartum to 4 DIM ruminal concentrations of propanol and ethanol increased with PT and ET, respectively. Postpartum, alcohol intake increased $49 \%$ in PT and $34 \%$ in ET from 4 to 29 d in milk, respectively. Ruminal concentrations of the alcohols remained unaffected by DIM. Treatments did not affect total ruminal volatile fatty acid concentrations, but the molar proportion of acetate increased in ET and the molar proportion of propionate increased in PT compared with the contrasting treatment. Propanol treatment decreased milk fat content at 15 to 29 DIM compared with ET. The net portal release of propanol and ethanol increased with increasing ruminal concentration of the respective alcohol. The portal release of alcohol accounted for 43 to $85 \%$ of ingested propanol and 36 to $57 \%$ of ingested ethanol. Hepatic uptake of
\end{abstract}

Received November 11, 2010.

Accepted January 17, 2011.

${ }^{1}$ Corresponding author: nbk@agrsci.dk propanol and ethanol equaled the net portal flux and no effect of treatment was detected for net splanchnic release of propanol and ethanol. In conclusion, ruminal metabolism is a major component of alcohol metabolism in dairy cows. The postpartum transition dairy cow has sufficient metabolic capacity to cope with high dietary concentrations of primary alcohols even when alcohol intake is abruptly increased at the day of calving. Alcohol intake affects milk fat content and alcohol composition of silage might be important to improve predictions of milk composition.

Key words: liver metabolism, rumen metabolism, silage alcohol, transition dairy cow

\section{INTRODUCTION}

Alcohols and low-molecular weight esters are normal constituents in silages at various concentrations, depending on the fermentation profile (Kristensen et al., 2010). Ethanol concentrations from 12 to $15 \mathrm{~g} / \mathrm{kg}$ of DM are common in corn silages (McDonald et al., 1991; Raun and Kristensen, 2010), and most dairy cows are, therefore, adapted to some ethanol intake. The concentration of the propanol in corn silage is more variable (Raun and Kristensen, 2010). The characteristic odor of Lactobacillus buchneri-fermented silages, associated with higher concentrations of acetic acid and propanol (Kristensen et al., 2010), have spurred debate among farmers and veterinarians, as they suspect propanol to negatively affect dairy cow performance and health. However, documentation for this association between propanol and cow performance is not available.

Silage inoculation with $L$. buchneri has been found to increase aerobic stability of corn silage (Driehuis et al., 1999) and has gained popularity as a heterofermentative silage inoculant in recent years (Kleinschmit and Kung, 2006). However, with the use of heterofermentative inoculants, a consistent increase of propanol concentration in corn silage has been observed (Kristensen et al., 2010), and in case of any unintended metabolic effects of propanol for dairy cows, these effects might escalate with increasing use of L. buchneri.

In corn silage samples collected at 20 randomly selected Danish dairy farms that did not use heterofermentative inoculants, it was observed that 4 farms 
fed corn silage containing 5 to $9 \mathrm{~g}$ of propanol $/ \mathrm{kg}$ of DM (Raun and Kristensen, 2010), and when collecting corn silage from dairy farms based on chemical odor, concentrations up to $25 \mathrm{~g}$ of propanol $/ \mathrm{kg}$ of DM have been observed (N. B. Kristensen and B. M. L. Raun, unpublished data).

High intake of silage alcohols has previously been associated with low organoleptic quality of milk (Gordon and Morgan, 1972; Randby et al., 1999), but was not linked to any health problems of dairy cows. Dietary ethanol is partly metabolized by ruminal microbes (Pradhan and Hemken, 1970; Durix et al., 1991); however, ethanol is also readily absorbed across the rumen epithelium (Veresegyházy et al., 2003) and increasing alcohol intake is assumed to be followed by an increasing alcohol load on the liver (Jean-Blain et al., 1992). Kristensen et al. (2007b) found that propanol (5.6 g/ $\mathrm{kg}$ of DM) supplied with heterofermented corn silage did not have major effects on ruminal metabolism, and previous studies investigating production responses to heterofermented silage (Taylor et al., 2002) did not indicate that milk production or the metabolism of the cows were negatively affected by propanol intake. However, in bovine hepatic tissue the activity of alcohol dehydrogenase (ADH) is approximately 20\% of the ADH activity in the sheep liver (Kovár et al., 1983). Although cows in midlactation are capable of metabolizing more alcohol than commonly found in silage-based rations, the relatively low $\mathrm{ADH}$ activity in combination with an increased hepatic NEFA uptake in the postpartum transition period (Drackley, 1999) might cause hepatic alcohol overload, increase alcohol exposure of peripheral tissues, and induce additional metabolic stress on the transition dairy cow. Postpartum fat mobilization and increased hepatic fat infiltration might induce a more reduced state (higher $\mathrm{NADH}: \mathrm{NAD}+$ ) in hepatocytes and not only increase the lactate:pyruvate ratio (Zammit, 1990), but also the ethanol:acetate and propanol:propionate ratios, resulting in less efficient hepatic extraction of alcohols.

We hypothesized that dairy cows not adapted to high propanol intake prepartum had a low ruminal capacity for propanol fermentation during the first days of lactation and that the rumen would adapt to increasing alcohol intake by an increased ruminal alcohol degradation after prolonged feeding. We also hypothesized that dairy cows in the early postpartum period would have a lower hepatic capacity for metabolizing propanol absorbed to the portal blood compared with cows later in lactation and that the combined effects would be accumulation of propanol in peripheral blood.

The objective of the present study was to investigate ruminal fermentation, portal absorption, and hepatic metabolism of propanol and ethanol in postpartum transition dairy cows challenged with rations containing a high concentration of either ethanol or propanol immediately after parturition.

\section{MATERIALS AND METHODS}

The present experiment complied with the Danish Ministry of Justice Law no. 382 (June 10, 1987), Act no. 726 (September 9, 1993) concerning experiments with animals and care of experimental animals.

\section{Animals and Feeding}

Eight Danish Holstein cows entering their second lactation fitted with a ruminal cannula (\#1C, Bar Diamond, Parma, ID) and permanent indwelling catheters in the mesenteric vein, hepatic portal vein, hepatic vein, and an artery were used. Catheters were prepared and surgery was performed according to the procedures described by Larsen and Kristensen (2009). Cows underwent surgery $48 \pm 7 \mathrm{~d}$ before parturition.

Cows were randomly allocated to 1 of 4 experimental treatments in a 2 by 2 factorial arrangement of treatments in a randomized block design. Factor 1 was the control (calcium carbonate) versus 2-hydroxy-4(methylthio)-butanoic acid isopropyl ester $(1.5 \mathrm{~g} / \mathrm{kg}$ of DM as $2.6 \mathrm{~g}$ of MetaSmart/kg of DM; Adisseo France S.A.S., Antony, France) and factor 2 was high dietary ethanol (supplemented with $14 \mathrm{~g}$ of ethanol $/ \mathrm{kg}$ of DM; ET) versus high dietary propanol (supplemented with $14 \mathrm{~g}$ of propanol $/ \mathrm{kg}$ of DM; PT). Only factor 2 data are presented in the present paper. Treatments were administered as 4 corn silage-based TMR and feeding of the experimental TMR was initiated on the day of parturition (1 DIM). All experimental TMR had the same overall composition (Table 1). Immediately after mixing, the TMR were bagged in portions of 15 to 20 $\mathrm{kg}$, evacuated in a chamber vacuum packaging machine (Webomatic I22, Webo A/S, Årup, Denmark), and frozen at $-20^{\circ} \mathrm{C}$. During the feeding period, TMR were maintained at $-6^{\circ} \mathrm{C}$, and before feeding, vacuum bags were allowed to thaw overnight on the barn floor. Nine randomly selected vacuum bags from each TMR were used for feed analysis. Prepartum, all cows were offered the same nonlactation ration (Table 1) and feed allowance was restricted to $10 \mathrm{~kg}$ of $\mathrm{DM} / \mathrm{d}$. Cows were fed equally sized portions at 0800,1600 , and $2400 \mathrm{~h}$. Orts (target $5 \%$ postpartum; generally, no orts prepartum) were removed before the morning feeding. Cows were milked at 0530 and $1530 \mathrm{~h}$.

\section{Experimental Samplings}

Cows were sampled on d $15 \pm 5$ prepartum and at 4 , 15, and 29 DMI. On sampling days, continuous infusion 
Table 1. Composition of prepartum, ethanol treatment, and propanol treatment TMR

\begin{tabular}{|c|c|c|c|}
\hline \multirow[b]{2}{*}{ Composition } & \multirow[b]{2}{*}{ Prepartum } & \multicolumn{2}{|c|}{ Treatment } \\
\hline & & Ethanol & Propanol \\
\hline DM, \% & 48 & 41 & 41 \\
\hline \multicolumn{4}{|l|}{ Ingredient, $\mathrm{g} / \mathrm{kg}$ of $\mathrm{DM}$} \\
\hline Corn silage $\mathrm{I}^{1}$ & 450 & 400 & 400 \\
\hline Grass clover silage $^{2}$ & 200 & 250 & 250 \\
\hline Sodium hydroxide-treated wheat grain & 75 & 207 & 207 \\
\hline Molasses, sugar beet & 10 & 17 & 17 \\
\hline Straw from spring barley & 118 & - & - \\
\hline Soybean meal & 100 & 100 & 100 \\
\hline Sugar beet pulp, dried & 204 & - & - \\
\hline Mineral and vitamin premix ${ }^{3}$ & - & 6 & 6 \\
\hline Vitamin E premix ${ }^{4}$ & - & 1 & 1 \\
\hline Premix dry ${ }^{5}$ & 12 & - & - \\
\hline Urea & - & 2.5 & 2.5 \\
\hline Vegetable fat & 7.5 & 10 & 10 \\
\hline $\mathrm{NaCl}$ & 2.5 & - & - \\
\hline MetaSmart, dry ${ }^{6}$ & - & $0 / 2.6$ & $0 / 2.6$ \\
\hline $\mathrm{CaCO}_{3}{ }^{6}$ & - & $5.2 / 2.6$ & $5.2 / 2.6$ \\
\hline Chromium(III)oxide & 1 & 1 & 1 \\
\hline Ethanol & - & 14 & - \\
\hline Propanol & - & - & 14 \\
\hline \multicolumn{4}{|l|}{ Nutrient, $\mathrm{g} / \mathrm{kg}$ of DM } \\
\hline Ash & 56 & 63 & 62 \\
\hline $\mathrm{CP}$ & 144 & 155 & 155 \\
\hline Crude fat & 36 & 36 & 36 \\
\hline $\mathrm{NDF}$ & 358 & 273 & 270 \\
\hline Ethanol & 6.4 & 18.8 & 6.4 \\
\hline Propanol & 1.9 & 2.3 & 16.2 \\
\hline 2-Butanol & 0.06 & 0.09 & 0.13 \\
\hline Propanal & 0.02 & 0.01 & 0.03 \\
\hline Ethyl acetate & 0.24 & 0.36 & 0.24 \\
\hline Propyl acetate & 0.02 & 0.04 & 0.09 \\
\hline $\mathrm{P}$ & 0.34 & 0.32 & 0.32 \\
\hline $\mathrm{K}$ & 1.3 & 1.5 & 1.5 \\
\hline $\mathrm{Na}$ & 0.20 & 0.46 & 0.48 \\
\hline $\mathrm{S}$ & 0.21 & 0.19 & 0.19 \\
\hline $\mathrm{Cl}$ & 0.44 & 0.37 & 0.37 \\
\hline $\mathrm{CAB}, \mathrm{mEq} / \mathrm{kg}$ of $\mathrm{DM}$ & 176 & 363 & 363 \\
\hline $\mathrm{NE}_{\mathrm{L}}{ }^{7} \mathrm{MJ} / \mathrm{kg}$ of DM & 6.84 & 7.0 & 7.0 \\
\hline
\end{tabular}

${ }^{1}$ Chemical composition of corn silage: DM, $363 \mathrm{~g} / \mathrm{kg}$; ash, $31 \mathrm{~g} / \mathrm{kg}$ of DM; CP, $87 \mathrm{~g} / \mathrm{kg}$ of DM; NDF, $375 \mathrm{~g} / \mathrm{kg}$ of DM; starch, $320 \mathrm{~g} / \mathrm{kg}$ of DM; in vitro OM digestibility, $72.5 \%$.

${ }^{2}$ Chemical composition of grass clover silage: DM, $407 \mathrm{~g} / \mathrm{kg}$; ash, $86 \mathrm{~g} / \mathrm{kg}$ of DM; CP, $146 \mathrm{~g} / \mathrm{kg}$ of DM; NDF, $363 \mathrm{~g} / \mathrm{kg}$ of DM; in vitro OM digestibility, $78.8 \%$.

${ }^{3}$ Lactation premix (VM2, Vitfoss, Gråsten, Denmark) containing: Ca, 16\%; P, 5\%; Mg, 6.5\%; Na, 9\%; S, 0.5\%; vitamin A, $600 \mathrm{IU} / \mathrm{g}$; vitamin $\mathrm{D}_{3}, 190 \mathrm{IU} / \mathrm{g}$; vitamin E, 4,000 mg/kg; Mn, 4,000 mg/kg; Cu, 1,500 mg/kg; Co, $25 \mathrm{mg} / \mathrm{kg} ; \mathrm{Zn}, 4,500 \mathrm{mg} / \mathrm{kg} ; \mathrm{I}, 225 \mathrm{mg} / \mathrm{kg} ; \mathrm{Se}, 50 \mathrm{mg} / \mathrm{kg}$.

${ }^{4}$ Vitamin E premix (Suplex d-alfa E-50000, Vitfoss) containing: E-vitamin, $50,000 \mathrm{mg} / \mathrm{kg}$; vitamin E (natural origin), $33,557.08 \mathrm{mg} / \mathrm{kg}$.

${ }^{5}$ Premix dry (Gold d-alfa Bio Org. Selen, Vitfoss) containing: Ca, 2\%; P 4\%, Mg, $19.2 \%$; Na, 3.6\%; S, 8.3\%; vitamin A, 1,091 IU/g; vitamin $\mathrm{D}_{3}, 145 \mathrm{IU} / \mathrm{g}$; vitamin $\mathrm{E}$ (natural origin), 18,182 mg/kg; biotin, $91 \mathrm{mg} / \mathrm{kg}$; Mn, $3,636 \mathrm{mg} / \mathrm{kg}$; Cu, $909 \mathrm{mg} / \mathrm{kg}$; Co, $36 \mathrm{mg} / \mathrm{kg} ; \mathrm{Zn}, 6,364 \mathrm{mg} / \mathrm{kg}$.

${ }^{6}$ Treatments were arranged as a 2 by 2 factorial design and each treatment presented in the present paper was applied in combination with a ration containing $2.6 \mathrm{~g}$ of HMBi [2-hydroxy-4-(methylthio)-butanoic acid isopropyl ester; MetaSmart, Adisseo, Antony, France] $+2.6 \mathrm{~g}$ of $\mathrm{CaCO}_{3}$ or $5.2 \mathrm{~g}$ of $\mathrm{CaCO}_{3}$.

${ }^{7}$ Calculated at DMI levels of $10 \mathrm{~kg}$ of DMI/d prepartum and $20 \mathrm{~kg}$ of DMI/d postpartum using the non-additive NorFor feed evaluation system (http://www.norfor.info). Ethanol TMR was added as $415 \mathrm{~kJ}$ of ethanol/ $\mathrm{kg}$ of DM and propanol TMR was added as $470 \mathrm{~kJ}$ of propanol $/ \mathrm{kg}$ of DM not included in the calculated $\mathrm{NE}_{\mathrm{L}}$ concentrations.

of $p$-aminohippuric acid (pAH; $27.4 \pm 1.6 \mathrm{mmol} / \mathrm{h}$ ) into the mesenteric vein was initiated at 0630 . The $\mathrm{pAH}$ infusate was a 175 -mmol pAH/ $\mathrm{kg}$ solution (4-aminohippuric acid 99\%, Acros, Geel, Belgium) adjusted to $\mathrm{pH}$
7.4, filtered (Vacu Cap 0.8/0.2 $\mu \mathrm{m}$, Pall Corp., Ann Arbor, MI), and autoclaved. Eight sets of ruminal and blood samples were obtained $0.5 \mathrm{~h}$ before feeding, and $0.5,1.5,2.5,3.5,4.5,5.5$, and $6.5 \mathrm{~h}$ after feeding. Be- 
fore collecting the main blood samples, separate blood samples were obtained in 1-mL heparinized syringes. Main blood samples were collected by simultaneously drawing blood from the artery, hepatic portal vein, and hepatic vein into $20-\mathrm{mL}$ syringes. A total of 40 $\mathrm{mL}$ of blood was obtained from each catheter at every sampling time. Blood was immediately transferred to heparin and $\mathrm{K}_{3} \mathrm{EDTA}$ vacuettes (no 455051 and 455036, respectively; Greiner Bio-One GmbH, Kremsmünster, Austria) and placed on crushed ice. Plasma was harvested by centrifugation at $3,000 \times g$ for $20 \mathrm{~min}$ at $4^{\circ} \mathrm{C}$ and stored at $-20^{\circ} \mathrm{C}$ until analysis.

Ruminal fluid was sampled from the ventral ruminal sac by using an extended suction strainer (\#RT, Bar Diamond) and a 50-mL syringe. Immediately after $\mathrm{pH}$ reading (see below) a subsample of ruminal fluid was stabilized with metaphosphoric acid (5\% final concentration) and stored at $-20^{\circ} \mathrm{C}$. Milk samples were collected at both the a.m. and p.m. milking on the day of sampling and the day before. Cows were weighed on the day of sampling after last blood sampling and before the p.m. milking.

\section{Analytical Procedures}

Hematocrit was determined on heparin-stabilized arterial samples by centrifugation of capillary tubes at $13,000 \times g$ for 6 min at ambient temperature. Whole blood sampled in 1-mL syringes were directly taken for blood gas and oximetry analysis (ABL 520, Radiometer A/S, Copenhagen, Denmark).

Ruminal fluid $\mathrm{pH}$ was measured immediately after sampling using a combination electrode (PHC2002-8; Hach Lange APS, Brønshøj, Denmark) and a pH meter calibrated at pH 4.005 and 7.000 (PHM 240; Hach Lange APS) and stored at $-20^{\circ} \mathrm{C}$. Ruminal fluid was analyzed for VFA by gas chromatography as described by Kristensen et al. (1996).

Concentrations of ethanol, propanol, and acetone in plasma, as well as ethyl acetate and propyl acetate in ruminal fluid were determined by headspace GC-MS (Kristensen et al., 2007b). The values obtained for acetone represent the total amount of acetone + acetoacetate in the samples.

Plasma and ruminal fluid were analyzed for glucose (D-glucose oxidase) and L-lactate (L-lactate oxidase) concentrations with membrane-immobilized enzymes by using a YSI 7100 MBS Select Biochemistry Analyzer (YSI Inc., Yellow Springs, OH).

Deacetylated plasma pAH was analyzed by the method described by Harvey and Brothers, (1962) using a continuous flow analyzer (Autoanalyzer 3, method US216-72 Rev.1; Seal Analytical Ltd., Burgess Hill, UK). For deacetylation of pAH, plasma was deproteinized by mixing it with an equal volume of $20 \%$ trichloroacetic acid (wt/vol) and the supernatant was then incubated at $100^{\circ} \mathrm{C}$ for $1 \mathrm{~h}$ as described by Kristensen et al. (2009).

Plasma D-3-BHBA and NEFA (EDTA plasma) concentrations were determined by enzymatic assays $(\mathrm{RB}$ 1008 and FA 115, respectively; Randox Laboratories Ltd., Crumlin, UK), adapted for use on a Cobas Mira autoanalyzer. Plasma concentrations of VFA and insulin were determined in samples pooled within cow and DIM. Plasma VFA concentration was determined by gas chromatography according to Kristensen (2000) using a mass spectrometer as detector. Plasma insulin concentration was determined by a time-resolved fluoroimmunometric assay according to Løvendahl and Purup (2002).

Glucose, L-lactate, VFA, alcohol, and ester concentrations in feed were determined as described for plasma and ruminal fluid on water extracts of feed. Water extraction of feed was prepared as described previously (Kristensen et al., 2007b). Feed DM was determined after drying at $60^{\circ} \mathrm{C}$ for $48 \mathrm{~h}$ in a forced-air oven. Organic matter concentration was determined as DM - crude ash. Crude ash concentration was determined after combustion at $525^{\circ} \mathrm{C}$ for $6 \mathrm{~h}$. Crude fat concentration was determined as petroleum ether extract following acid hydrolysis (Stoldt, 1952). Neutral detergent fiber concentration was determined as described by (Mertens, 2002).

Milk was analyzed for fat, protein, and lactose (monohydrate) by infrared spectrometry using a Milko Scan 4000 (Eurofins Steins A/S, Holstebro, Denmark).

\section{Calculations and Statistical Procedures}

The whole blood concentrations of ethanol and propanol were obtained from plasma concentrations by correcting for the dilution space in erythrocytes (ethanol $=72 \pm 8 \%$ and propanol $=77 \pm 3 \% ; \mathrm{n}=8$ ). The alcohol dilution space in erythrocytes was determined by the method described previously for VFA by Kristensen (2000). In short, whole blood from 8 cows was spiked with known amounts of the alcohols and effective dilution volume in the erythrocyte fraction was determined by measuring alcohol concentrations in plasma harvested from the spiked blood using the same centrifugation procedure as used for the experimental samples. Net portal, net hepatic, and net splanchnic fluxes as well as net hepatic extraction and portal recoveries were calculated as described by Kristensen et al. (2007b) using either whole blood or plasma values as indicated. A positive net flux indicates a net release from a tissue bed and a negative net flux indicates a net 
uptake by the tissue bed. Energy-corrected milk yield was calculated according to Sjaunja et al. (1991).

Data for ruminal variables, arterial variables, as well as blood and plasma fluxes were analyzed as a complete randomized split plot design with a $2 \times 2$ factorial arrangement of treatments, with cow as the whole plot (blocks), treatment as the whole-plot factor, and DIM as the subplot factor using the mixed procedure in SAS. Cow was considered a random factor. The fixed effects of treatment factor 1 , treatment factor 2 , sampling time, DIM, as well as the possible interactions were included in the model. Sampling time within cow and DIM was considered as repeated measures using autoregressive order 1 covariance structure. Variables with 1 observation within cow and DIM (DMI, milk yield data, BW, plasma VFA, and plasma insulin) were analyzed using a reduced model, not including the effect of sampling time. Statistics in Tables 2 to 5 for effects of treatment, DIM, and treatment $\times$ DIM are computed using a data set containing only postpartum data. Data are presented as means \pm residual SEM and treatment means were separated using the SLICE option of the LSMEANS statement in the mixed procedure protected by the overall $F$-test. Also, $t$-tests for treatment effects on transition from prepartum to 4 DIM (i.e., test for prepartum ET to 4 DIM ET to differ from prepartum PT to 4 DIM PT; named $P_{\text {Trans } \times \text { trt }}$ in tables) as well as for prepartum to differ from 4 DIM (named $P_{\text {Trans }}$ in tables) were performed using the ESTIMATE statement. Significance was declared at $P$ $\leq 0.05$ and tendencies considered at $0.05<P \leq 0.10$.

\section{RESULTS}

\section{Feed Intake, Milk Yield, and BW}

Voluntary DMI increased from prepartum to 4 DIM and with DIM $(P<0.01)$, but was not affected by treatment $(P=0.52$; Table 2$)$. Postpartum, ethanol intake was greater $(P<0.01)$ in ET compared with $\mathrm{PT}$, and propanol intake was greater $(P<0.01)$ in PT compared with ET. Alcohol intake increased $(P<0.01)$ with DIM proportional to DMI.

Milk, ECM, and protein yield were not affected by treatment $(P=0.74$ to 0.98$)$. A tendency $(P=$ 0.06 ) for a treatment $\times$ DIM effect on fat yield and an interaction $(P=0.01)$ for treatment $\times$ DIM on milk fat concentration was found, reflecting a greater yield and milk fat concentration at 15 and 29 DIM in ET compared with PT. Milk yield, ECM, milk fat yield, and milk lactose content increased with DIM $(P<0.01$ to $P=0.05)$. Milk protein concentration decreased with DIM $(P<0.01)$, but milk protein yield was not affected by DIM $(P=0.99)$. Body weights decreased with increasing DIM $(P=0.03)$, but were not affected by treatment $(P=0.24)$.

\section{Ruminal Variables}

Ruminal pH and concentrations of glucose, L-lactate, ammonia, and total VFA were not affected by treatment or DIM ( $P=0.16$ to 0.94 ; Table 3$)$. Postpartum, the molar proportion of acetate was greater $(P<0.01)$ in ET compared with $\mathrm{PT}$, and the molar proportion of propionate was greater $(P=0.04)$ in $\mathrm{PT}$ compared with ET. The treatment effects on ruminal acetate and propionate were apparent at 4 DIM, whereas the levels were comparable between treatment groups prepartum and, accordingly, tendencies for transition $\times$ treatment interactions were observed ( $P=0.07$ to 0.09 ).

The molar proportion of butyrate was not consistently affected by treatments or DIM, although a tendency $(P$ $=0.08)$ for a treatment $\times$ DIM interaction and a DIM effect $(P=0.04)$ were observed. Postpartum, the molar proportions of isobutyrate and valerate decreased $(P$ $=0.02$ and $P<0.01$, respectively). The molar proportion of isovalerate was not affected $(P=0.53$ and 0.24 , respectively) by treatment or DIM. A tendency $(P=0.10)$ for a treatment $\times$ DIM interaction was observed for the molar proportion of caproate, reflecting a greater molar proportion at 4 and 15 DIM in ET compared with PT.

From prepartum to 4 DIM, ruminal concentrations of propanol increased $(P<0.01)$ more $(1.7 \pm 0.2 \mathrm{mM})$ in PT compared with ET and ruminal concentrations of ethanol increased $(P<0.01)$ more $(2.6 \pm 0.3 \mathrm{mM})$ in ET compared with PT. Postpartum, no effects $(P=$ 0.64 and 0.87 , respectively) of DIM were observed on ruminal concentrations of ethanol and propanol. Ruminal ethyl acetate increased at parturition $(P<0.01)$ and the concentration decreased $(P=0.04)$ slightly with increasing DIM without being affected $(P=0.98)$ by treatment. The ruminal concentration of propyl acetate increased more $(P<0.01)$ in PT compared with ET at parturition and remained greater $(P<0.01)$ in PT compared with ET postpartum.

\section{Arterial Variables}

Arterial plasma insulin and glucose concentrations decreased and arterial acetone and NEFA concentrations increased from postpartum to 4 DIM $(P<0.01$ to $P=0.02$; Table 4 ), but were not affected by treatment in the transition period or postpartum. Postpartum, plasma insulin and BHBA concentrations increased and arterial lactate and NEFA concentrations decreased with DIM $(P \leq 0.01)$. A treatment $\times$ DIM interaction $(P=0.04)$ for arterial plasma L-lactate and BHBA 
Table 2. DMI, milk yield, milk composition, and BW ${ }^{1}$

\begin{tabular}{|c|c|c|c|c|c|c|c|c|c|c|c|c|c|c|}
\hline \multirow[b]{2}{*}{ Item } & \multicolumn{2}{|c|}{ Prepartum $^{2}$} & \multirow[b]{2}{*}{$P_{\text {Trans }}$} & \multirow[b]{2}{*}{$P_{\text {Trans } \times \text { trt }}^{3}$} & \multicolumn{2}{|c|}{$4 \mathrm{DIM}$} & \multicolumn{2}{|c|}{15 DIM } & \multicolumn{2}{|c|}{29 DIM } & \multirow[b]{2}{*}{$\mathrm{SEM}^{4}$} & \multicolumn{3}{|c|}{$P$-value ${ }^{5}$} \\
\hline & Ethanol & Propanol & & & Ethanol & Propanol & Ethanol & Propanol & Ethanol & Propanol & & Trt & DIM & Trt $\times$ DIM \\
\hline DMI, $\mathrm{kg} / \mathrm{d}$ & 10.3 & 10.3 & $<0.01$ & 0.46 & 14.7 & 13.8 & 16.5 & 17.5 & 19.7 & 20.6 & 0.6 & 0.52 & $<0.01$ & 0.32 \\
\hline Ethanol intake, $\mathrm{mmol} / \mathrm{d}$ & 1,399 & 1,399 & $<0.01$ & $<0.01$ & 5,864 & $1,885^{*}$ & 6,598 & $2,376^{*}$ & 7,879 & $2,807^{*}$ & 154 & $<0.01$ & $<0.01$ & 0.02 \\
\hline $\begin{array}{l}\text { Propanol intake, mmol/d } \\
\text { Yield, kg/d }\end{array}$ & 329 & 329 & $<0.01$ & $<0.01$ & 554 & $3,726^{*}$ & 623 & $4,729^{*}$ & 744 & $5,563^{*}$ & 145 & $<0.01$ & $<0.01$ & $<0.01$ \\
\hline Milk & - & - & - & - & 26.2 & 27.2 & 33.8 & 34.5 & 36.5 & 39.4 & 3.2 & 0.74 & $<0.01$ & 0.44 \\
\hline $\mathrm{ECM}^{6}$ & - & - & - & - & 29.8 & 31.7 & 35.6 & 33.5 & 37.6 & 36.8 & 3.0 & 0.93 & 0.01 & 0.29 \\
\hline Milk fat & - & - & - & - & 1.2 & 1.4 & 1.5 & 1.3 & 1.6 & 1.5 & 0.1 & 0.75 & 0.05 & 0.06 \\
\hline Milk protein & - & - & - & - & 1.2 & 1.1 & 1.1 & 1.1 & 1.1 & 1.2 & 0.1 & 0.98 & 0.99 & 0.55 \\
\hline Milk composition & & & & & & & & & & & & & & \\
\hline Fat, $\mathrm{g} / \mathrm{kg}$ & - & - & - & - & 46 & $53 \dagger$ & 45 & 39 & 45 & $38 \dagger$ & 2 & 0.52 & $<0.01$ & 0.01 \\
\hline Protein, $\mathrm{g} / \mathrm{kg}$ & - & - & - & - & 44 & $39^{*}$ & 33 & 33 & 30 & 30 & 1 & 0.11 & $<0.01$ & 0.06 \\
\hline Lactose, $\mathrm{g} / \mathrm{kg}$ & - & - & - & - & 46 & 46 & 49 & 49 & 50 & 49 & 1 & 0.88 & $<0.01$ & 0.91 \\
\hline $\mathrm{BW}, \mathrm{kg}$ & 647 & 629 & $<0.01$ & 0.17 & 628 & 583 & 595 & 561 & 586 & 574 & 17 & 0.24 & 0.03 & 0.34 \\
\hline
\end{tabular}

${ }^{1}$ Cows received supplementation with $14 \mathrm{~g}$ of propanol $/ \mathrm{kg}$ of DM (propanol treatment) or $14 \mathrm{~g}$ of ethanol $/ \mathrm{kg}$ of DM (ethanol treatment) from the day of calving.

${ }^{2}$ Prepartum, all cows were fed the same diet.

${ }^{3}$ Student $t$-test to observe the effects that treatments might have on arterial variables from prepartum to 4 DIM. Trans $=$ transition, trt $=$ treatment.

${ }^{4}$ Residual standard error of the means $(\mathrm{n}=4)$.

${ }^{5}$ Fixed effects postpartum. Trt $=$ treatment.

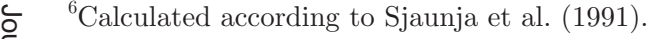

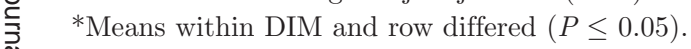

$\stackrel{\mathrm{O}}{\mathrm{O}} \dagger$ Means within DIM and row tended to differ $(P \leq 0.10)$. 
Table 3. Ruminal variables ( $\mathrm{mmol} / \mathrm{L}$, unless otherwise indicated $)^{1}$

\begin{tabular}{|c|c|c|c|c|c|c|c|c|c|c|c|c|c|c|}
\hline \multirow[b]{2}{*}{ Item } & \multicolumn{2}{|c|}{ Prepartum $^{2}$} & \multirow[b]{2}{*}{$P_{\text {Trans }}$} & \multirow[b]{2}{*}{$P_{\text {Trans } \times \text { trt }}^{3}$} & \multicolumn{2}{|c|}{$4 \mathrm{DIM}$} & \multicolumn{2}{|c|}{15 DIM } & \multicolumn{2}{|c|}{29 DIM } & \multirow[b]{2}{*}{$\mathrm{SEM}^{4}$} & \multicolumn{3}{|c|}{$P$-value ${ }^{5}$} \\
\hline & Ethanol & Propanol & & & Ethanol & Propanol & Ethanol & Propanol & Ethanol & Propanol & & Trt & DIM & Trt $\times$ DIM \\
\hline $\mathrm{pH}$ & 6.69 & 6.76 & $<0.01$ & 0.97 & 6.43 & 6.50 & 6.46 & 6.55 & 6.55 & 6.53 & 0.07 & 0.60 & 0.28 & 0.51 \\
\hline Glucose & 0.018 & 0.012 & $<0.01$ & 0.41 & 0.013 & 0.004 & 0.009 & 0.005 & 0.012 & 0.006 & 0.003 & 0.16 & 0.52 & 0.47 \\
\hline L-Lactate & 0.99 & 1.83 & 0.46 & 0.95 & 0.70 & 1.59 & 1.20 & 1.28 & 0.88 & 0.83 & 0.33 & 0.22 & 0.52 & 0.37 \\
\hline Ammonium & 5.2 & 5.0 & 0.28 & 0.22 & 5.2 & 4.0 & 4.8 & 4.1 & 4.4 & 4.2 & 0.6 & 0.32 & 0.80 & 0.61 \\
\hline Total VFA & 92 & 85 & $<0.01$ & 0.77 & 110 & 105 & 111 & 106 & 108 & 105 & 5 & 0.49 & 0.85 & 0.94 \\
\hline Acetate, $\mathrm{mol} / 100 \mathrm{~mol}$ & 64.0 & 64.0 & $<0.01$ & 0.09 & 59.6 & $57.9 \dagger$ & 60.4 & $57.1^{*}$ & 60.3 & $57.5^{*}$ & 0.6 & $<0.01$ & 0.94 & 0.27 \\
\hline Propionate, $\mathrm{mol} / 100 \mathrm{~mol}$ & 18.0 & 19.1 & $<0.01$ & 0.07 & 22.2 & $25.3^{*}$ & 21.3 & $24.8^{*}$ & 22.0 & 23.2 & 0.8 & 0.04 & 0.17 & 0.14 \\
\hline Isobutyrate, $\mathrm{mol} / 100 \mathrm{~mol}$ & 0.9 & 1.0 & $<0.01$ & 0.34 & 0.7 & 0.8 & 0.7 & 0.7 & 0.7 & 0.7 & 0.04 & 0.32 & 0.02 & 0.43 \\
\hline Butyrate, mol/100 mol & 14.0 & 12.7 & $<0.01$ & 0.86 & 12.5 & 11.1 & 13.2 & 12.8 & 12.7 & 14.2 & 0.6 & 0.86 & 0.04 & 0.08 \\
\hline Isovalerate, $\mathrm{mol} / 100 \mathrm{~mol}$ & 1.2 & 1.3 & $<0.01$ & 0.79 & 1.7 & 1.8 & 1.4 & 1.8 & 1.5 & 1.5 & 0.2 & 0.53 & 0.24 & 0.27 \\
\hline Valerate, $\mathrm{mol} / 100 \mathrm{~mol}$ & 1.3 & 1.4 & $<0.01$ & 0.99 & 2.0 & 2.0 & 1.8 & 1.9 & 1.7 & 1.8 & 0.1 & 0.41 & $<0.01$ & 0.94 \\
\hline Caproate, $\mathrm{mol} / 100 \mathrm{~mol}$ & 0.5 & 0.5 & $<0.01$ & 0.12 & 1.2 & 1.0 & 1.2 & 0.9 & 1.0 & 1.0 & 0.1 & 0.15 & 0.47 & 0.10 \\
\hline Ethanol & 0.6 & 0.6 & $<0.01$ & $<0.01$ & 3.2 & $1.5^{*}$ & 3.3 & $1.7^{*}$ & 2.8 & $1.6^{*}$ & 0.3 & $<0.01$ & 0.64 & 0.70 \\
\hline Propanol & 0.3 & 0.2 & $<0.01$ & $<0.01$ & 0.5 & $1.9^{*}$ & 0.5 & $1.9^{*}$ & 0.5 & $1.8^{*}$ & 0.3 & $<0.01$ & 0.87 & 0.98 \\
\hline Ethyl acetate & 0.10 & 0.11 & $<0.01$ & 0.67 & 0.20 & 0.20 & 0.21 & 0.20 & 0.18 & 0.19 & 0.02 & 0.98 & 0.04 & 0.92 \\
\hline Propyl acetate & 0.02 & 0.02 & $<0.01$ & $<0.01$ & 0.04 & $0.09^{*}$ & 0.05 & $0.08^{*}$ & 0.03 & $0.06^{*}$ & 0.01 & $<0.01$ & 0.12 & 0.54 \\
\hline
\end{tabular}

${ }^{1}$ Cows received supplementation with $14 \mathrm{~g}$ of propanol $/ \mathrm{kg}$ of DM (propanol treatment) or $14 \mathrm{~g}$ of ethanol $/ \mathrm{kg}$ of DM (ethanol treatment) from the day of calving.

${ }^{2}$ Prepartum, all cows were fed the same diet.

${ }^{3}$ Student $t$-test to observe the effects that treatments might have on arterial variables from prepartum to 4 DIM. Trans $=$ transition, trt $=$ treatment.

${ }^{4}$ Residual standard error of the means $(\mathrm{n}=4)$.

${ }^{5}$ Fixed effects postpartum. Trt $=$ treatment.

*Means within DIM and row differed $(P \leq 0.05)$.

$\dagger$ Means within DIM and row tended to differ $(P \leq 0.10)$. 
Table 4. Arterial variables (mmol/L, unless otherwise indicated $)^{1}$

\begin{tabular}{|c|c|c|c|c|c|c|c|c|c|c|c|c|c|c|}
\hline \multirow[b]{2}{*}{ Item } & \multicolumn{2}{|c|}{ Prepartum $^{2}$} & \multirow[b]{2}{*}{$P_{\text {Trans }}$} & \multirow[b]{2}{*}{$P_{\text {Trans } \times \text { trt }}{ }^{3}$} & \multicolumn{2}{|c|}{$4 \mathrm{DIM}$} & \multicolumn{2}{|c|}{15 DIM } & \multicolumn{2}{|c|}{29 DIM } & \multirow[b]{2}{*}{$\mathrm{SEM}^{4}$} & \multicolumn{3}{|c|}{$P$-value ${ }^{5}$} \\
\hline & Ethanol & Propanol & & & Ethanol & Propanol & Ethanol & Propanol & Ethanol & Propanol & & Trt & DIM & Trt $\times$ DIM \\
\hline \multicolumn{15}{|l|}{ Blood plasma } \\
\hline Insulin, $\mathrm{p} M^{7}$ & 100 & 101 & $<0.01$ & 0.84 & 31 & 28 & 31 & 26 & 59 & 69 & 8 & 0.84 & $<0.01$ & 0.62 \\
\hline Glucose & 3.99 & 3.92 & 0.02 & 0.39 & 3.38 & 3.62 & 3.29 & 3.41 & 4.07 & 3.55 & 0.23 & 0.82 & 0.11 & 0.18 \\
\hline L-Lactate & 0.52 & 0.55 & 0.72 & 0.22 & 0.48 & $0.57^{*}$ & 0.33 & 0.32 & 0.37 & 0.33 & 0.02 & 0.42 & $<0.01$ & 0.04 \\
\hline BHBA & 0.78 & 0.75 & 0.11 & 0.16 & 0.77 & 0.60 & 0.95 & $0.66^{*}$ & 0.86 & 0.86 & 0.07 & 0.13 & 0.01 & 0.04 \\
\hline Acetone + acetoacetate $^{6}$ & 0.079 & 0.069 & $<0.01$ & 0.65 & 0.247 & 0.204 & 0.317 & 0.328 & 0.244 & 0.275 & 0.044 & 1.00 & 0.11 & 0.66 \\
\hline NEFA & 0.086 & 0.119 & $<0.01$ & 0.72 & 0.304 & 0.359 & 0.257 & 0.214 & 0.163 & 0.120 & 0.034 & 0.77 & $<0.01$ & 0.12 \\
\hline \multicolumn{15}{|l|}{ Whole blood } \\
\hline $\mathrm{pH}$ & 7.44 & 7.44 & 0.83 & 0.02 & 7.43 & $7.45^{*}$ & 7.42 & 7.43 & 7.44 & 7.43 & 0.01 & 0.10 & 0.03 & 0.03 \\
\hline Hematocrit, \% & 29.5 & 30.2 & 0.14 & 0.01 & 34.2 & 28.8 & 30.7 & 27.8 & 29.1 & 26.9 & 2.2 & 0.31 & 0.01 & 0.24 \\
\hline $\mathrm{O}_{2}$ & 5.67 & 5.76 & 0.14 & 0.02 & 6.58 & 5.53 & 5.99 & 5.16 & 5.61 & 5.19 & 0.43 & 0.27 & $<0.01$ & 0.16 \\
\hline $\mathrm{CO}_{2}$ & 23.9 & 23.0 & $<0.01$ & 0.08 & 25.8 & 27.1 & 26.6 & 26.8 & 26.2 & 25.9 & 0.8 & 0.69 & 0.58 & 0.41 \\
\hline Ethanol & 0.005 & 0.003 & 0.08 & 0.63 & 0.042 & 0.025 & 0.067 & 0.033 & 0.068 & 0.044 & 0.021 & 0.30 & 0.44 & 0.89 \\
\hline Propanol & 0.006 & 0.004 & 0.15 & 0.48 & 0.009 & 0.011 & 0.012 & 0.013 & 0.011 & 0.019 & 0.005 & 0.53 & 0.33 & 0.56 \\
\hline Acetate & 1.9 & 1.8 & 0.06 & 0.05 & 1.9 & $1.5^{*}$ & 2.3 & $1.8^{*}$ & 2.4 & $2.0^{*}$ & 0.1 & 0.02 & $<0.01$ & 0.72 \\
\hline Propionate & 0.032 & 0.030 & $<0.01$ & 0.95 & 0.084 & 0.081 & 0.085 & 0.106 & 0.078 & 0.094 & 0.012 & 0.47 & 0.27 & 0.41 \\
\hline Isobutyrate $^{7}$ & 0.003 & 0.005 & $<0.01$ & 0.20 & 0.006 & $0.009^{*}$ & 0.006 & $0.012^{*}$ & 0.008 & $0.016^{*}$ & 0.007 & $<0.01$ & $<0.01$ & $<0.01$ \\
\hline Butyrate & 0.019 & 0.014 & $<0.01$ & 0.08 & 0.056 & 0.032 & 0.067 & 0.052 & 0.056 & 0.066 & 0.007 & 0.25 & 0.05 & 0.07 \\
\hline Isovalerate & 0.004 & 0.003 & $<0.01$ & 0.69 & 0.006 & 0.005 & 0.008 & 0.006 & 0.007 & 0.008 & 0.001 & 0.47 & $<0.01$ & 0.05 \\
\hline Valerate & $<0.001$ & $<0.001$ & 0.06 & 0.48 & 0.001 & 0.001 & 0.001 & 0.001 & 0.001 & 0.001 & 0.0004 & 0.51 & 0.60 & 0.77 \\
\hline Caproate & $<0.001$ & $<0.001$ & $<0.01$ & 0.50 & 0.002 & 0.001 & 0.002 & $<0.001$ & 0.001 & 0.001 & 0.0006 & 0.31 & 0.23 & 0.09 \\
\hline
\end{tabular}

${ }^{1}$ Cows received supplementation with $14 \mathrm{~g}$ of propanol $/ \mathrm{kg}$ of DM (propanol treatment) or $14 \mathrm{~g}$ of ethanol $/ \mathrm{kg}$ of DM (ethanol treatment) from the day of calving.

${ }^{2}$ Prepartum, all cows were fed the same diet.

${ }^{3}$ Student $t$-test to observe the effects that treatments might have on arterial variables from prepartum to 4 DIM. Trans $=$ transition, trt $=$ treatment.

${ }^{4}$ Residual standard error of the means $(\mathrm{n}=4)$.

${ }^{5}$ Fixed effects postpartum. Trt $=$ treatment.

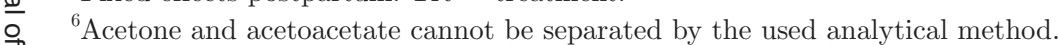

In Interactions between factor 1 and factor $2(P \leq 0.05)$. Factor 1 was the control (calcium carbonate) versus 2 -hydroxy-4-(methylthio)-butanoic acid isopropyl ester $(1.5 \mathrm{~g} / \mathrm{kg}$ of DM 疍. as $2.6 \mathrm{~g}$ of MetaSmart $/ \mathrm{kg}$ of DM; Adisseo France S.A.S., Antony, France) and factor 2 was high dietary ethanol (supplemented with $14 \mathrm{~g}$ of ethanol/kg of DM) versus high dietary œ propanol (supplemented with $14 \mathrm{~g}$ of propanol $/ \mathrm{kg}$ of DM)

ब. $\quad *$ Means within DIM and row differed $(P \leq 0.05)$. 


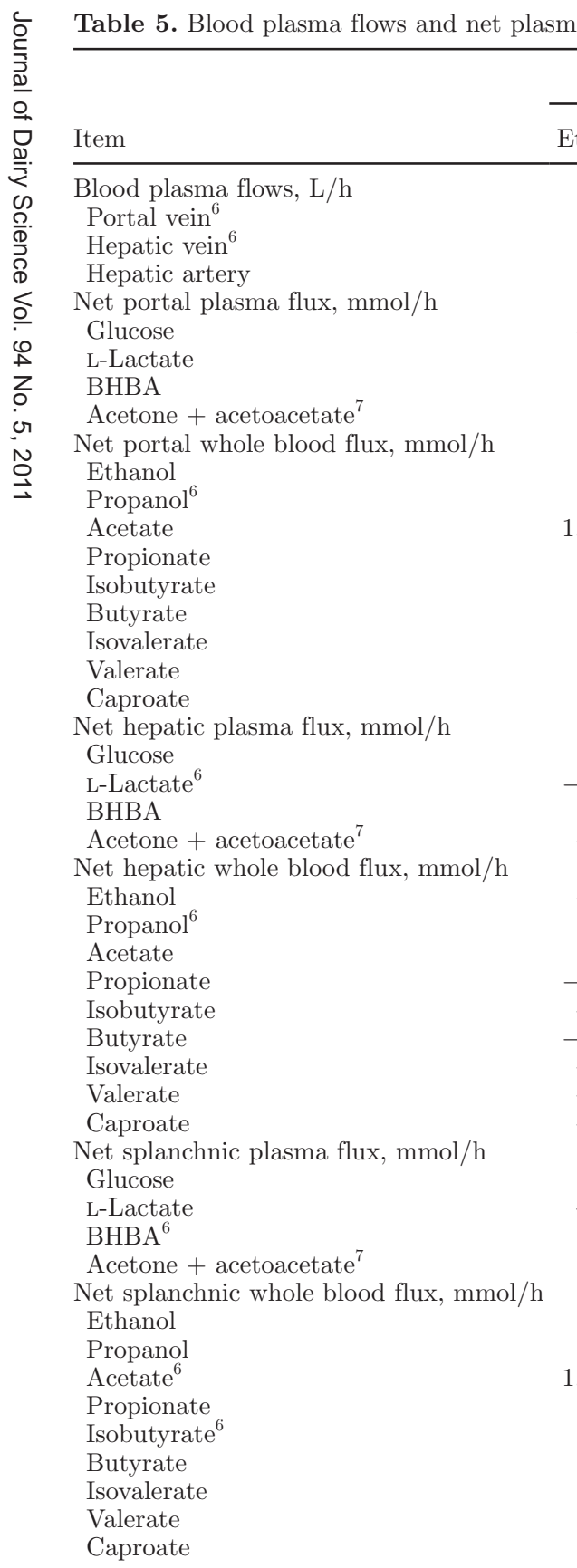

$\frac{\text { Prepartum }^{2}}{\text { Ethanol Propanol }} P_{\text {Trans }} P_{\text {Trans } \times \text { trt }}^{3} \frac{4 \text { DIM }}{\text { Ethanol Propanol }}$

15 DIM

Ethanol Propanol

$\begin{array}{llllllll}705 & 679 & <0.01 & 0.45 & 911 & 934 & 1,071 & 1,145\end{array}$

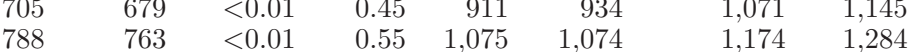

$\begin{array}{rrrrrrrr}88 & 763 & <0.01 & 0.55 & 1,075 & 1,074 & 1,174 & 1,284 \\ 83 & 83 & <0.01 & 0.45 & 167 & 137 & 103 & 140\end{array}$

$\begin{array}{llllll}-14 & -20 & <0.01 & 0.33 & 24 & -1\end{array}$

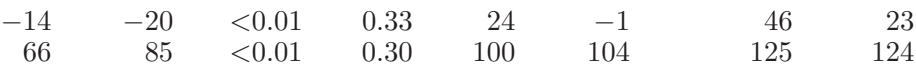

$\begin{array}{rrrrrr}136 & 126 & 0.87 & 0.71 & 139 & 120 \\ 56 & 55 & 0.24 & 0.96 & 45 & 44\end{array}$

$\begin{array}{rrrrrr}23 & 25 & <0.01 & 0.03 & 87 & 34^{*} \\ 9 & 10 & <0.01 & <0.01 & 19 & 80^{*}\end{array}$

$\begin{array}{rr}9 & 10 \\ 1,567 & 1,378\end{array}$

$\begin{array}{rrrrrr}510 & 505 & <0.01 & 0.87 & 1,919 & 1,783\end{array}$

52
124

14

19

22
99

99
13
18

18

$0.17 \quad 0.89$

$0.13 \quad 0.96$

$<0.01 \quad 0.65$

72
177

$177 \quad 142$

$\begin{array}{ll}45 & 38 \\ 56 & 40\end{array}$

$\begin{array}{llllll}296 & 317 & <0.01 & 0.84 & 553 & 571\end{array}$

$-111-117$

$\begin{array}{rrrrrr}119 & 113 & <0.01 & 0.29 & -250 & -291 \\ -58 & -55 & 0.02 & 0.86 & -38 & -38\end{array}$

$-58 \quad-55$

$<0.01$

$\begin{array}{rrrrrc}-25 & -29 & 0.23 & 0.97 & -55 & -44 \\ -9 & -12 & <0.01 & <0.01 & -19 & -85^{*} \\ 0 & 82 & <0.01 & 0.03 & 483 & 218\end{array}$

$\begin{array}{rrrrrr}-480 & -475 & <0.01 & 0.03 & 483 & 218 \\ -22 & -21 & 0.01 & 0.58 & -685 & -778\end{array}$

$\begin{array}{rrrrrr}-22 & -21 & 0.53 & 0.94 & -22 & -20\end{array}$

$\begin{array}{llllll}-104 & -84 & 0.27 & 0.88 & -139 & -111\end{array}$

$\begin{array}{rrrrrr}-12 & -12 & 0.42 & 0.64 & -13 & -13\end{array}$

$\begin{array}{llllll}-19 & -17 & <0.01 & 0.70 & -44 & -38 \\ -18 & -14 & <0.01 & 0.44 & -58 & -42\end{array}$

$\begin{array}{rrrrrr}282 & 297 & <0.01 & 0.56 & 579 & 570\end{array}$

$\begin{array}{llllll}-45 & -32 & <0.01 & 0.23 & -150 & -186\end{array}$

$\begin{array}{rrrrrr}256 & 238 & <0.01 & 0.12 & 397 & 304^{*} \\ -1.8 & 0.1 & 0.18 & 0.80 & 6.0 & 6.9\end{array}$

$\begin{array}{rrrrrr}-2.1 & -4.0 & <0.01 & <0.01 & 27.4 & -10.4^{*} \\ -0.5 & -1.6 & 0.43 & 0.48 & -0.2 & -4.6\end{array}$

$\begin{array}{ccrrrr}-0.5 & -1.6 & 0.43 & 0.48 & -0.2 & -4.6 \\ 1,567 & 1,460 & <0.01 & 0.30 & 2,402 & 2,001\end{array}$

29

30

$<0.01$

$0.08 \quad 0.80 \quad 77$

$\begin{array}{ll}0.02 & 0.95\end{array}$

$\begin{array}{ll}0.08 & 0.37\end{array}$

$0.58 \quad 0.54$

0.58

179

$\begin{array}{ll}70 & 79\end{array}$

$2,208 \quad 2,088$

$\begin{array}{rr}895 & 997 \\ 26 & 24\end{array}$

$\begin{array}{rr}26 & 24 \\ 18 & 201\end{array}$

$\begin{array}{ll}18 & 16 \\ 50 & 45\end{array}$

$\begin{array}{ll}71 & 46\end{array}$

$531 \quad 622$

$-191 \quad-201$

$\begin{array}{ll}269 & 211 \\ -76 & -73\end{array}$

$-120-65^{*}$

$\begin{array}{rl}-21 & -95 \\ 321 & 335\end{array}$

$\begin{array}{rr}321 & 335 \\ -816 & -876\end{array}$

$\begin{array}{ll}-26 & -22\end{array}$

$-178-151$

$\begin{array}{ll}-15 & -13 \\ -50 & -45\end{array}$

$-73 \quad-45$

$577 \quad 644$

$\begin{array}{rr}-66 & -77 \\ 449 & 381\end{array}$

$\begin{array}{cc}449 & 381 \\ -5.9 & 6.2\end{array}$

$\begin{array}{ll}-5.8 & -8.9\end{array}$

$\begin{array}{cc}-1.0 & -8 . \\ 2,529 & 2,424\end{array}$

$79 \quad 12$

$\begin{array}{rr}0 & 2 \\ 50 & 50 \\ 3 & 3\end{array}$

3
0
0
29 DIM

$P$-value ${ }^{5}$

$\begin{aligned} 114 & 56^{*} \\ 19 & 87^{*}\end{aligned}$

$\begin{array}{rrrrrr}1,061 & 1,170 & 53 & 0.33 & <0.01 & 0.59 \\ 1,228 & 1,323 & 45 & 0.31 & <0.01 & 0.11 \\ 167 & 153 & 36 & 0.98 & 0.20 & 0.26 \\ & & & & & \\ 21 & 30 & 12 & 0.30 & 0.06 & 0.20 \\ 140 & 144 & 11 & 0.91 & <0.01 & 0.86 \\ 185 & 197 & 28 & 0.83 & <0.01 & 0.57 \\ 84 & 119 & 15 & 0.46 & <0.01 & 0.20 \\ & & & & & \\ 144 & 52^{*} & 18 & 0.02 & 0.03 & 0.29 \\ 22 & 101^{*} & 8 & <0.01 & 0.37 & 0.52 \\ 2,377 & 2,544 & 282 & 0.94 & 0.03 & 0.57 \\ 1,075 & 1,096 & 137 & 0.65 & 0.12 & 0.91 \\ 28 & 28 & 3 & 0.89 & 0.01 & 0.60 \\ 246 & 310 & 44 & 0.99 & 0.07 & 0.42 \\ 20 & 20 & 2 & 0.89 & 0.08 & 0.63 \\ 52 & 57 & 7 & 0.81 & 0.23 & 0.63 \\ 63 & 68 & 11 & 0.38 & 0.25 & 0.23 \\ & & & & & \\ 672 & 679 & 35 & 0.43 & <0.01 & 0.14 \\ -267 & -221 & 17 & 0.79 & <0.01 & 0.13 \\ 266 & 299 & 21 & 0.16 & <0.01 & 0.01 \\ -87 & -111 & 12 & 0.71 & <0.01 & 0.18 \\ & & & & & \\ -172 & -61^{*} & 16 & 0.01 & <0.01 & 0.02 \\ -25 & -106^{*} & 9 & <0.01 & 0.54 & 0.54 \\ 625 & 331 & 200 & 0.54 & 0.05 & 0.01 \\ -995 & -975 & 125 & 0.77 & 0.11 & 0.85 \\ -29 & -25 & 3 & 0.43 & <0.01 & 0.47 \\ -192 & -240 & 40 & 0.96 & 0.10 & 0.46 \\ -17 & -16 & 2 & 0.84 & 0.11 & 0.58 \\ -51 & -57 & 7 & 0.83 & 0.23 & 0.60 \\ -63 & -68 & 11 & 0.34 & 0.31 & 0.18 \\ & & & & & \\ 693 & 709 & 33 & 0.57 & <0.01 & 0.30 \\ -127 & -78 & 19 & 0.96 & <0.01 & 0.16 \\ 451 & 496 & 31 & 0.21 & <0.01 & 0.06 \\ -3.6 & 8.3 & 8.3 & 0.44 & 0.44 & 0.40 \\ & & & & & \\ -27.4 & -8.9 & 9.4 & 0.26 & <0.01 & <0.01 \\ -3.0 & -5.3 & 2.7 & 0.14 & 0.60 & 0.56 \\ 3,002 & 2,875 & 131 & 0.15 & <0.01 & 0.46 \\ 80 & 122 & 17 & 0.15 & 0.41 & 0.50 \\ -1 & 3 * & 1 & 0.03 & 0.56 & 0.29 \\ 54 & 70 & 7 & 0.60 & 0.01 & 0.29 \\ 3 & 4 & 1 & 0.68 & 0.72 & 0.56 \\ 1 & 1 & 1 & 0.68 & 0.66 & 0.75 \\ 0 & 0 & 1 & 0.14 & 0.01 & 0.03\end{array}$


reflected an increased concentration of L-lactate at 4 DIM and a lower concentration of BHBA at 15 DIM in PT compared with ET.

Arterial whole blood $\mathrm{pH}$ increased in PT and decreased in ET $(P=0.02)$ from prepartum to 4 DIM. An interaction $(P=0.03)$ for treatment $\times$ DIM on arterial blood $\mathrm{pH}$ reflected a higher blood $\mathrm{pH}$ at 4 DIM in PT compared with ET. Arterial whole blood hematocrit and $\mathrm{O}_{2}$ concentrations increased in ET and decreased in PT from prepartum to 4 DIM, but were not otherwise affected by treatment. Arterial $\mathrm{CO}_{2}$ concentrations tended to increase $(P=0.08)$ more in $\mathrm{PT}$ from prepartum to 4 DIM, but no effect of treatment or DIM was detected postpartum.

Despite a numerical increase $(P=0.08$ and $P=0.15)$ from prepartum to 4 DIM in arterial concentrations of ethanol and propanol, the alcohols were not affected significantly by treatment or DIM postpartum or by transition. However, during the 8-h sampling window within a sampling day, the arterial blood concentration of ethanol and propanol increased $(P<0.01)$ immediately after feeding, but decreased to pre-feeding levels within 3.5 to $4.5 \mathrm{~h}$ after feeding (Figure 1 and 2).

The arterial acetate concentration increased $(P=$ 0.05) in ET compared with PT from prepartum to 4 DIM and remained greater $(P=0.02)$ in ET postpartum. The arterial propionate concentration increased $(P<0.01)$ from prepartum to 4 DIM, but was not otherwise affected by treatment or DIM. Arterial butyrate increased from postpartum to 4 DIM, but was not consistently affected by treatments or DIM, although a tendency $(P=0.07)$ for a treatment $\times$ DIM interaction and a DIM effect $(P=0.05)$ were observed.

\section{Blood Flows}

All blood plasma flows increased $(P<0.01$; Table 5$)$ from prepartum to 4 DIM and the portal and hepatic blood plasma flows also increased $(P<0.01)$ postpartum. However, blood flows were not affected by treatment $(P=0.31$ to 0.98$)$.

\section{Net Portal Fluxes}

From prepartum to 4 DIM, the net portal flux of ethanol increased $(P=0.03$; Table 5$)$ more in ET compared with $\mathrm{PT}$ and the net portal flux of propanol increased $(P<0.01)$ more in PT compared with ET. Postpartum, the net portal flux of propanol was, on average, $1,662 \pm 84 \mathrm{mmol} / \mathrm{d}$ greater in PT compared with ET $(P<0.01)$ and the net portal flux of ethanol was, on average, $1,618 \pm 428 \mathrm{mmol} / \mathrm{d}$ greater in ET compared with PT $(P=0.02)$. The net portal flux of ethanol increased with DIM in both treatments $(P=$ 


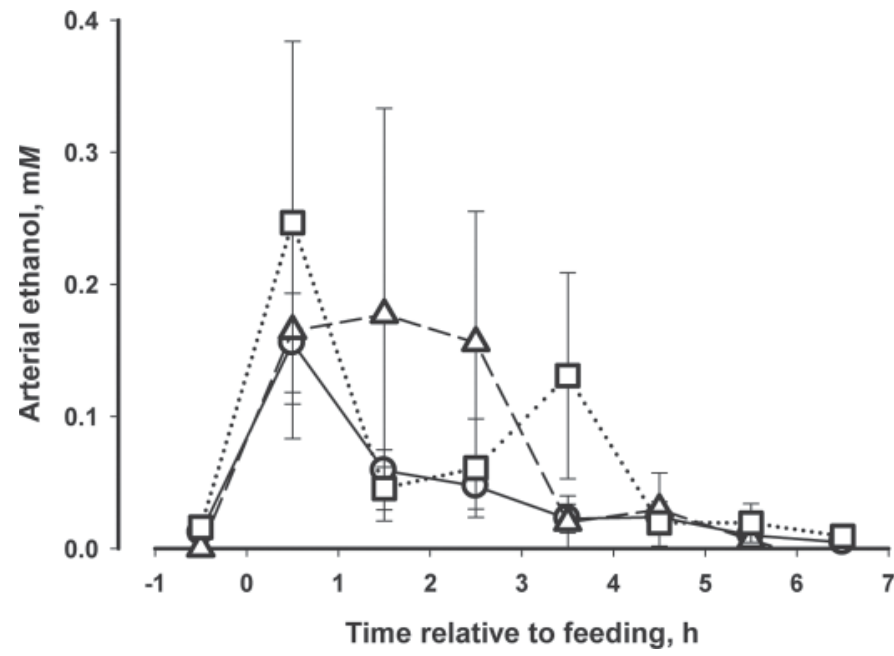

Figure 1. Arterial concentration of ethanol in whole blood with ethanol treatment in an 8-h sampling window at 4 DIM (O), 15 DIM $(\Delta)$, and 29 DIM $(\square)$. The postpartum TMR was supplemented with $14 \mathrm{~g}$ of ethanol $/ \mathrm{kg}$ of DM (ethanol treatment). The arterial blood concentration of ethanol was affected $(P<0.01)$ by time relative to feeding, reflecting a postprandial increase in ethanol, although the effect was numerically small. Each data point is the mean of 4 observations \pm standard error of the means.

0.03). Net portal fluxes of ethanol and propanol correlated $(r=0.72, P<0.01$ and $r=0.73, P<0.01)$ with ruminal concentrations of ethanol and propanol, respectively.

In line with substitution of ground wheat in the prepartum ration with sodium hydroxide-treated wheat grain in the postpartum rations, the net portal flux of glucose shifted $(P<0.01)$ from a negative net flux prepartum to a generally positive net flux postpartum, with the exception of the net flux at 4 DIM in PT. However, no differences between treatments on net portal flux of glucose were observed and a tendency $(P$ $=0.06)$ for a postpartum DIM showed no consistent trend.

Net portal fluxes of L-lactate, acetate, propionate, valerate, and caproate all increased $(P<0.01$ to 0.04$)$ from prepartum to 4 DIM. Postpartum, net portal fluxes of L-lactate, BHBA, acetone, acetate, isobutyrate, butyrate, and isovalerate increased or tended to increase $(P<0.01$ to $P=0.08)$ with DIM.

\section{Net Hepatic Fluxes}

The hepatic release of glucose, BHBA, and acetate, and the hepatic uptake of L-lactate, propanol, valerate, and caproate increased $(P \leq 0.01$; Table 5$)$ from prepartum to 4 DIM. However, only BHBA, propanol, and acetate fluxes were affected by treatment. Release of BHBA and acetate increased $(P=0.05$ and $P=0.03)$ more in ET compared with $\mathrm{PT}$, and propanol uptake increased $(P<0.01)$ more in $\mathrm{PT}$ compared with ET The hepatic uptake of acetone + acetoacetate decreased $(P=0.02)$ from prepartum to 4 DIM, but increased $(P$ $<0.01)$ postpartum in both treatments.

A treatment $\times$ DIM interaction $(P=0.01)$ was observed for the net hepatic release of BHBA and acetate, reflecting a smaller $(P<0.05)$ release of BHBA at 4 and 15 DIM and a numerically smaller release of acetate at 4 and 29 DIM in PT compared with ET.

The net hepatic uptake of ethanol increased with DIM; however, the increase was greater in ET compared with PT (interaction treatment $\times \mathrm{DIM}, P=0.02$ ). The net hepatic uptake of propanol was greater $(P<0.01)$ in PT compared with ET.

Postpartum, the net hepatic release of glucose increased $(P<0.01)$ with DIM and the net hepatic uptake of acetone, isobutyrate, and butyrate increased or tended to increase $(P<0.01$ to $P=0.10)$ with DIM. The uptake of L-lactate was affected by DIM postpartum, but no consistent pattern was observed.

\section{Net Splanchnic Fluxes}

The net splanchnic release of glucose, BHBA, acetate, propionate, isobutyrate, butyrate, isovalerate, and caproate, and the net splanchnic uptake of L-lactate increased $(P<0.01$ to $P=0.08$; Table 5$)$ from prepartum to 4 DIM. The prepartum to 4 DIM difference in net splanchnic flux of ethanol was affected by treatment $(P$ $<0.01$ ), reflecting a net splanchnic release of ethanol

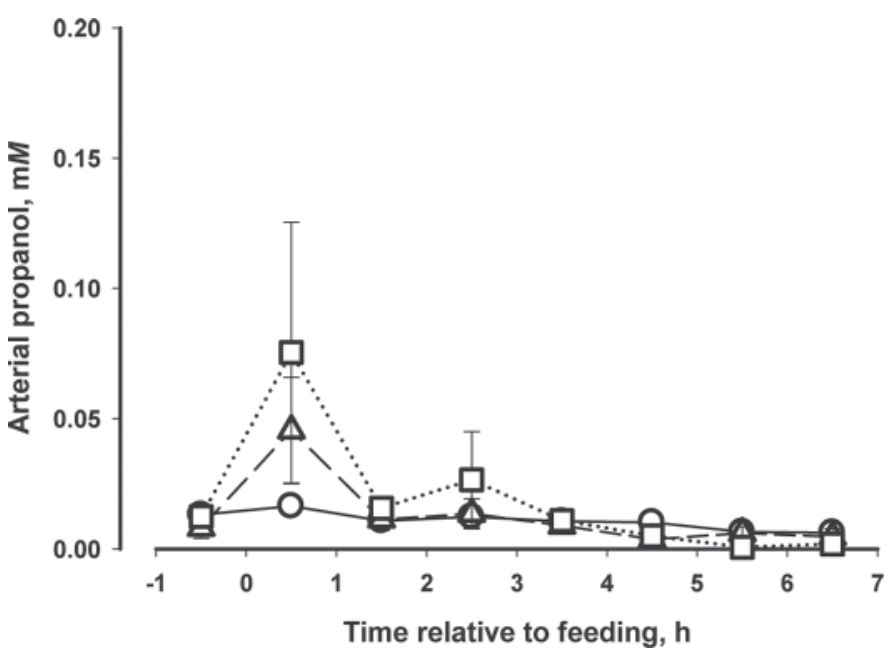

Figure 2. Arterial concentration of propanol in whole blood with propanol treatment in an 8-h sampling window at 4 DIM (O), 15 DIM $(\Delta)$ and 29 DIM $(\square)$. The postpartum TMR was supplemented with $14 \mathrm{~g}$ of propanol $/ \mathrm{kg}$ of DM (propanol treatment). The arterial blood concentration of propanol was affected $(P<0.01)$ by time relative to feeding, reflecting a postprandial increase in ethanol, although the effect was numerically small. Each data point is the mean of 4 observations \pm standard error of the means. 
at 4 DIM in ET compared with a net splanchnic uptake in PT. The net splanchnic flux of propanol was not affected by treatment or DIM, but the overall flux was negative $(-4 \pm 1 \mathrm{mmol} / \mathrm{h}, P=0.05)$.

A tendency $(P=0.06)$ for a treatment $\times$ DIM interaction was observed for net splanchnic flux of BHBA, reflecting a lower flux at 4 DIM in PT compared with ET, and a treatment $\times$ DIM interaction $(P=0.03)$ was observed for net splanchnic flux of caproate, reflecting a greater net splanchnic uptake in ET compared with PT. The net splanchnic uptake of caproate and L-lactate decreased $(P \leq 0.01)$ with DIM and the net splanchnic release of $\mathrm{BHBA}$, glucose, acetate, and butyrate, increased $(P \leq 0.01)$ with DIM. Net splanchnic release of isobutyrate was higher $(P=0.03)$ in $\mathrm{PT}$ compared with ET.

\section{Hepatic Extraction}

The hepatic extraction ratio of ethanol was not affected by transition or treatment from prepartum to 4 DIM. Postpartum, a treatment $\times$ DIM interaction $(P$ $<0.01$; Table 5) was observed, reflecting a tendency for increased hepatic extraction of ethanol at 4 DIM in PT, and a decreased hepatic extraction of ethanol at 15 DIM in PT compared with ET. Hepatic extraction of ethanol was affected by DIM $(P<0.01)$, reflecting relatively large variation in extraction estimates between sampling days. The hepatic extraction ratio of ethanol in PT remained relatively stable among sampling days and was maintained at prepartum levels. The hepatic extraction of propanol tended $(P=0.08)$ to increase from prepartum to 4 DIM, but overall, no effects of treatment or DIM were observed for extraction of propanol. The overall postpartum estimates for hepatic extraction ratios for ethanol and propanol were similar, being $68 \pm 8 \%$ for ethanol and $72 \pm 7 \%$ for propanol. Hepatic extraction of lactate increased from prepartum to 4 DIM (24 to $41 \pm 2 \% ; P<0.01)$ and the hepatic extraction did not change $(P=0.47)$ with DIM postpartum.

\section{Portal Recovery of Dietary Alcohols}

The portal recovery of dietary ethanol was not affected by transition, treatment or DIM, and the net portal flux accounted in the postpartum period for 45 $\pm 4 \%$ of dietary ethanol (Table 5 ). The portal recovery of propanol decreased $(P=0.01)$ from prepartum to 4 DIM in PT compared with ET and postpartum portal propanol recovery tended $(P=0.10)$ to be lower in $\mathrm{PT}$ compared with ET. Postpartum, the net portal flux of propanol accounted for $78 \pm 12 \%$ and $46 \pm 12 \%$ of dietary propanol in ET and PT, respectively.

\section{DISCUSSION}

We hypothesized that postpartum transition dairy cows, due to a limited ruminal and hepatic capacity for alcohol metabolism, would encounter metabolic problems when challenged with a high daily intake of propanol from the day of parturition. The alcohol intake used in the present study was equivalent to high silage alcohol concentrations in field studies (Kristensen et al., 2007b; Raun and Kristensen, 2010). However, none of the cows showed any apparent indications of insufficient metabolic capacity for alcohol metabolism with daily intakes of 300 to $400 \mathrm{~g}$ of propanol compared with an intake of 300 to $400 \mathrm{~g}$ of ethanol, and none of the cows developed any clinical signs of metabolic diseases nor did the intake of propanol compared with ethanol depress DMI or milk yield.

\section{Ruminal Alcohol Metabolism}

The present study showed in agreement with previous studies on ethanol that ruminal fermentation is an important component in alcohol metabolism in dairy cattle (Orskov et al., 1967; Frederiksen and Ochia, 1970; Pradhan and Hemken, 1970). Portal absorption accounted for 36 to $57 \%$ of ingested ethanol and 43 to $85 \%$ of ingested propanol (lowest recovery with greatest intake), suggesting that rumen microbial metabolism, and first-pass rumen epithelial metabolism, account for approximately half of the ingested alcohol dose. Hence, ruminal metabolism markedly decreases the amounts of dietary ethanol as well as propanol reaching the liver.

Alcohol dehydrogenases are ubiquitously expressed in nature and participate in interconversions among alcohols, aldehydes, and ketones in both eukaryotes and prokaryotes (Reid and Fewson, 1994). The lack of adaptation in ruminal alcohol metabolism with prolonged exposure to alcohol intake indicates that ruminal microbial $\mathrm{ADH}$ and epithelium $\mathrm{ADH}$ abundance was not increased in response to the supplemented alcohol. However, it has previously been observed that ruminal alcohol metabolism was greater in cows fed a high-grain diet, inducing ruminal ethanol production, compared with a diet containing more hay (Pradhan and Hemken, 1970). Also sub-acute ruminal acidosis in calves induced substantial ruminal alcohol production (Kristensen et al., 2007a), indicating that starch-induced ruminal alcohol production might be important in adaptation of rumen microbial as well as intermediary metabolic pathways of alcohol metabolism. Alcohol ingested with silage before parturition might also have contributed to the adaptation to alcohol metabolism.

Low dietary concentrations of propanol (in ET) tended to increase portal recovery and might reflect that 
ruminally produced propanol is a major component of total available propanol with low dietary concentrations. In a previous study, it was observed that portal recoveries of ethanol and propanol were close to $100 \%$ (Kristensen et al., 2007b) of dietary intake when feeding with lower alcohol concentrations compared with the present study.

Ruminal VFA composition was consistently affected by alcohol intake (i.e., the molar percentage of acetate increased with ET and propionate increased with PT). However, it was not possible to detect an effect of treatment on net portal fluxes of acetate and propionate. Our inability to detect a response in net portal flux of acetate (derived from ethanol) and propionate (derived from propanol) was probably due to large variation on these estimates $(\mathrm{SEM}=282$ and $137 \mathrm{mmol} / \mathrm{h}$, respectively) compared with the treatment differences for ethanol $(116 \pm 16 \mathrm{mmol} / \mathrm{h})$ and propanol $(99 \pm$ $6 \mathrm{mmol} / \mathrm{h}$ ). It is, therefore, likely that the increase in ruminal acetate and propionate, in fact, increased portal uptake of acetate and propionate with high dietary ethanol and propanol, respectively, but we were unable to detect it.

\section{Microbial Versus Epithelial Alcohol Metabolism}

In the present study, it was not possible to assess the relative importance of rumen microbial and rumen epithelial metabolic pathways involved in metabolism of dietary alcohol not accounted for in the portal blood. Connor et al. (2010) reported a large increase in ADH mRNA abundance in ruminal epithelium of weaned calves fed grain, which indicates a role of the rumen epithelium in metabolizing the alcohols and alcohol esters generated in the rumen under SARA conditions (see above). This also suggests that part of the dietary alcohols not accounted for in the portal blood in the present experiment might have been metabolized in the epithelium during absorption. First-pass metabolism has been suggested as a barrier against systemic toxicity of alcohol (Julkunen et al., 1985) and, in humans, gastrointestinal ADH is considered an important factor in the toxic effects of ethanol exerted through both intestinal microbial and gut epithelial-expressed enzymes converting ethanol to acetaldehyde (Seitz and Oneta, 1998). Acetaldehyde fluxes were not quantified in the present study, but rumen epithelial ADH might have contributed to first-pass alcohol metabolism. We observed an increased net hepatic acetate release with ET not accounted for by increased ethanol uptake, and acetaldehyde production might be a quantitatively important substrate for hepatic acetate production.

Considerably lower alcohol concentrations were observed in ruminal fluid compared with concentrations in the human gut after alcohol consumption. This suggests that rumen epithelium is less likely damaged by alcohol, although it cannot be completely ruled out that rumen epithelial production of reactive aldehydes, in combination with direct effects of alcohols, could induce epithelial damage and potentially facilitate translocation of endotoxins to portal blood (Bode and Bode, 2003).

\section{Hepatic Metabolism of Ethanol and Propanol}

The human liver is known to have a limited capacity for ethanol metabolism and extensive alcohol consumption can induce liver damage (Hawkins and Kalant, 1972). Lower ADH activity in bovine tissues compared with that in pigs and sheep (Kovár et al., 1983), together with a significant portal uptake of alcohols in the postpartum transition period, was hypothesized to increase arterial alcohol concentrations. However, in the present study, arterial concentrations of propanol increased temporarily and peaked at a very low concentration (Figure 2) as hepatic uptake of propanol mirrored the portal uptake, even though the portal uptake of propanol increased abruptly from prepartum to 4 DIM. For ethanol, the transient postprandial increase in arterial ethanol at 4 DIM represented an ethanol concentration of only $0.02 \%$. These data strongly indicate that dairy cows have a sufficient hepatic capacity for metabolism of propanol and ethanol, even in the postpartum transition period when also the NEFA load of the liver was increased.

In case of high NADH:NAD + ratio in the liver, induced by fat mobilization (Zammit, 1990), and hepatic alcohol metabolism postpartum, the cow could be hypothesized to suffer from a markedly increased hepatic lactate:pyruvate ratio and, consequently, decreased substrate flux to gluconeogenesis. However, we observed an increased hepatic extraction of lactate from prepartum to postpartum (24 to $40 \pm 2 \%$; $P<$ 0.01 ) and the hepatic extraction did not change with DIM postpartum, indicating that the increased alcohol absorption postpartum, in combination with modestly increased plasma NEFA concentrations postpartum, did not inhibit the transition-induced increase in hepatic lactate extraction. Lactate did not accumulate in plasma postpartum and variables related to glucose metabolism indicated little response to PT compared with ET in the present study, with relatively low plasma NEFA concentrations (i.e., no differences could be detected for arterial insulin, glucose, or net fluxes of glucose or lactate). The only indication for a treatment effect on glucogenic status was an increased arterial concentration of lactate at $4 \mathrm{DIM}$ in $\mathrm{PT}$ compared with ET. 
The arterial concentration of lactate was increased in both ET and PT at 4 DIM compared with prepartum concentrations and, as such, do not indicate that the increased hepatic uptake of lactate observed at 4 DIM compared with 15 and 29 DIM was driven as much by an increased supply from peripheral tissues as by an increased hepatic pull. A large hepatic pull on plasma lactate to support gluconeogenesis at 4 DIM would be expected to decrease arterial concentrations of lactate, but the opposite was observed in the present as well as in a previous study (Larsen and Kristensen, 2009). Reynolds et al. (2003) observed a decreased arterial lactate concentration at 11 to 21 DIM compared with the prepartum concentration, in agreement with the decrease observed in the present study from 4 to 15 DIM.

Contrary to the limited apparent effect of treatments on glucose metabolism, a strong ketogenic shift appeared to happen, comparing ET with PT. Increased hepatic output of acetate and BHBA in ET compared with PT seems to have been the main driver of this shift, although the large variation on hepatic acetate output makes it difficult to accurately assess the extent of this component's effect on the ketogenic shift. The numerical differences in net hepatic acetate and BHBA release were generally much greater than the increased ethanol uptake. However, the variability, especially in acetate release, hampers our ability to determine how likely it is that other carbon sources absorbed from the gut (e.g., acetaldehyde) are involved in supplying ketogenic carbon to the liver.

\section{Milk Composition}

The expected negative correlation between energy balance and milk fat content (Grieve et al., 1986) probably explains that milk composition at 4 DIM was less affected by treatment compared with milk composition at 15 and 29 DIM, when the 2 contrasting alcohol treatments had stronger effects on milk fat content. Despite the possible use of milk composition to predict energy balance of cows, this approach is prone to large variation (Løvendahl et al., 2010) and the present study indicates that variation in silage alcohol concentrations might have to be considered as an important source of bias in models based on milk composition data. Both ruminal and arterial acetate concentrations increased with ET and arterial acetate might, therefore, be an important driver of milk fat production at 15 and 29 DIM, in agreement with effects observed in studies supplementing glucogenic substrate by infusion (Rigout et al., 2002).

\section{CONCLUSIONS}

Rumen microbial and rumen epithelial metabolism are major components of alcohol metabolism in dairy cows. Alcohol ingestion increased ruminal concentrations of the corresponding VFA (ethanol-to-acetate and propanol-to-propionate) ratios without apparent adaptation in metabolism from 4 to 29 DIM. The liver effectively cleared absorbed alcohols both in pre- and postpartum cows and alcohols did not accumulate in arterial blood. The postpartum transition dairy cow with moderate plasma NEFA concentrations postpartum had sufficient metabolic capacity to cope with high concentrations of primary alcohols relative to the range observed in silage-based rations. Alcohol intake affected milk fat content and alcohol composition of silage might be important to improve predictions of milk composition.

\section{ACKNOWLEDGMENTS}

We thank Birgit H. Løth, Adam Storm, and Pia Jensen (Faculty of Agricultural Sciences, Aarhus University, Tjele, Denmark) for their skilful and dedicated technical assistance during surgery, care of animals, and sampling. We also gratefully acknowledge Birgit H. Løth and Anne Krustrup for skillful laboratory assistance and the staff of K-33 (Faculty of Agricultural Sciences, Aarhus University) for their assistance. Funding for the study was provided by Mælkeafgiftsfonden (\#29-2008; Aarhus, Denmark), the Directorate for Food, Fisheries and Agri Business (Copenhagen, Denmark; \#3304-VMP-05-005), and the Danish Ministry of Food, Agriculture and Fisheries (Copenhagen, Denmark).

\section{REFERENCES}

Bode, C., and J. C. Bode. 2003. Effect of alcohol consumption on the gut. Best Pract. Res. Clin. Gastroenterol. 17:575-592.

Connor, E. E., R. W. Li, R. L. Baldwin VI, and C. Li. 2010. Gene expression in the digestive tissues of ruminants and their relationships with feeding and digestive processes. Animal 4:993-1007.

Drackley, J. K. 1999. ADSA Foundation Scholar Award: Biology of dairy cows during the transition period: The final frontier? J. Dairy Sci. 82:2259-2273.

Driehuis, F., S. J. W. H. Oude Elferink, and S. F. Spoelstra. 1999. Anaerobic lactic acid degradation during ensilage of whole crop maize inoculated with Lactobacillus buchneri inhibits yeast growth and improves aerobic stability. J. Appl. Microbiol. 87:583-594.

Durix, A., C. Jean-Blain, H. P. Sallmann, and J. P. Jouany. 1991. Use of a semicontinuous culture system (RUSITEC) to study the metabolism of ethanol in the rumen and its effects on ruminal digestion. Can. J. Anim. Sci. 71:115-123.

Frederiksen, J. H. J., and B. A. Ochia. 1970. The effect of ethanol and acetic acid on milk yield and milk composition of cows given rations high in concentrates. Acta Agric. Scand. 20:17-24.

Gordon, D. T., and M. E. Morgan. 1972. Principal volatile compounds in feed flavored milk. J. Dairy Sci. 55:905-912. 
Grieve, D. G., S. Korver, Y. S. Rijpkema, and G. Hof. 1986. Relationship between milk composition and some nutritional parameters in early lactation. Livest. Prod. Sci. 14:239-254.

Harvey, R. B., and A. J. Brothers. 1962. Renal extraction of paraaminohippurate and creatinine measured by continuous in vivo sampling of arterial and renal-vein blood. Ann. N. Y. Acad. Sci. 102:46-54.

Hawkins, R. D., and H. Kalant. 1972. The metabolism of ethanol and its metabolic effects. Pharmacol. Rev. 24:67-157.

Jean-Blain, C., A. Durix, and B. Tranchant. 1992. Kinetics of ethanol metabolism in sheep. Reprod. Nutr. Dev. 32:83-90.

Julkunen, R. J. K., C. Di Padova, and C. S. Lieber. 1985. First pass metabolism of ethanol - A gastrointestinal barrier against the systematic toxicity of ethanol. Life Sci. 37:567-573.

Kleinschmit, D. H., and L. Kung Jr. 2006. A meta-analysis of the effects of Lactobacillus buchneri on the fermentation and aerobic stability of corn and grass and small-grain silages. J. Dairy Sci. 89:4005-4013.

Kovár, J., P. Racek, and V. Vlcková. 1983. Alcohol dehydrogenase activity and isoenzyme distribution in the organs of cow, pig and sheep. Comp. Biochem. Physiol. B 76:161-165.

Kristensen, N. B. 2000. Quantification of whole blood short-chain fatty acids by gas chromatographic determination of plasma 2-chloroethyl derivatives and correction for dilution space in erythrocytes. Acta Agric. Scand. A Anim. Sci. 50:231-326.

Kristensen, N. B., A. Danfær, V. Tetens, and N. Agergaard. 1996. Portal recovery of intraruminally infused short-chain fatty acids in sheep. Acta Agric. Scand. A Anim. Sci. 46:26-38.

Kristensen, N. B., B. A. Røjen, B. M. L. Raun, A. C. Storm, L. Puggaard, and M. Larsen. 2009. Hepatic acetylation of the blood flow marker $p$-aminohippuric acid affect measurement of hepatic blood flow in cattle. Pages 558-559 in XIth International Symposium on Ruminant Physiology, Clermont-Ferrand, France. Y. Chilliard, F. Glasser, Y. Faulconnier, F. Bocquier, I. Veissier, and M. Doreau, ed. Wageningen Academic Publishers, Wageningen, the Netherlands.

Kristensen, N. B., J. Sehested, S. K. Jensen, and M. Vestergaard. 2007a. Effect of milk allowance on concentrate intake, ruminal environment, and ruminal development in milk-fed Holstein calves. J. Dairy Sci. 90:4346-4355.

Kristensen, N. B., K. H. Sloth, O. Højberg, N. H. Spliid, C. Jensen, and R. Thøgersen. 2010. Effects of microbial inoculants on corn silage fermentation, microbial contents, aerobic stability, and milk production under field conditions. J. Dairy Sci. 93:3764-3774.

Kristensen, N. B., A. Storm, B. M. L. Raun, B. A. Røjen, and D. L. Harmon. 2007b. Metabolism of silage alcohols in lactating dairy cows. J. Dairy Sci. 90:1364-1377.

Larsen, M., and N. B. Kristensen. 2009. Effect of abomasal glucose infusion on splanchnic and whole-body glucose metabolism in periparturient dairy cows. J. Dairy Sci. 92:1071-1083.

Løvendahl, P., and H. M. Purup. 2002. Technical note: Time-resolved fluoro-immunometric assay for intact insulin in livestock species. J. Anim. Sci. 80:191-195.
Løvendahl, P., C. Ridder, and N. C. Friggens. 2010. Limits to prediction of energy balance from milk composition measurements at individual cow level. J. Dairy Sci. 93:1998-2006.

McDonald, P., N. Henderson, and S. Heron. 1991. The Biochemistry of Silage. 2nd ed. Chalcombe Publications, Bucks, UK.

Mertens, D. R. 2002. Gravimetric determination of amylase-treated neutral detergent fiber in feeds with refluxing in beakers or crucibles: Collaborative study. J. AOAC Int. 85:1217-1240.

Orskov, E. R., R. W. Hemken, and L. A. Moore. 1967. Effect of ethanol infusion on milk fat content and composition and on volatile fatty acids in the rumen liquor. J. Dairy Sci. 50:692-695.

Pradhan, K., and R. W. Hemken. 1970. Utilization of ethanol and its effect on fatty acid patterns in ruminants. J. Dairy Sci. 53:17391746

Randby, Å. T., I. Selmer-Olsen, and L. Baevre. 1999. Effect of ethanol in feed on milk flavor and chemical composition. J. Dairy Sci. $82: 420-428$

Raun, B. M. L., and N. B. Kristensen. 2010. Propanol in maize silage at Danish dairy farms. Acta Agric. Scand. A Anim. Sci. 60:53-59.

Reid, M. F., and C. A. Fewson. 1994. Molecular characterization of microbial alcohol dehydrogenases. Crit. Rev. Microbiol. 20:13-56.

Reynolds, C. K., P. C. Aikman, B. Lupoli, D. J. Humphries, and D. E. Beever. 2003. Splanchnic metabolism of dairy cows during the transition from late gestation through early lactation. J. Dairy Sci. 86:1201-1217.

Rigout, S., S. Lemosquet, J. E. van Eys, J. W. Blum, and H. Rulquin. 2002. Duodenal glucose increases glucose fluxes and lactose synthesis in grass silage-fed dairy cows. J. Dairy Sci. 85:595-606.

Seitz, H. K., and C. M. Oneta. 1998. Gastrointestinal alcohol dehydrogenase. Nutr. Rev. 56:52-60.

Sjaunja, L. O., L. Baevre, L. Junkkarinen, J. Pedersen, and J. Setälä. 1991. A Nordic proposal for an energy corrected milk (ECM) formula. Pages 156-157 in Proc. 27th Session of International Committee for Recording Productivity of Milk Animals (ICRPMA). Eur. Assoc. Anim. Prod. Publ. No. 50 Eur. Assoc. Anim. Prod., Wageningen, the Netherlands.

Stoldt, W. 1952. Vorschlag zur Vereinheitlichung der Fettbestimmung in Lebensmitteln. Fette und Seifen 54:206-207.

Taylor, C. C., N. J. Ranjit, J. A. Mills, J. M. Neylon, and L. Kung Jr. 2002. The effect of treating whole-plant barley with Lactobacillus buchneri 40788 on silage fermentation, aerobic stability, and nutritive value for dairy cows. J. Dairy Sci. 85:1793-1800.

Veresegyházy, T., H. Fébel, G. Nagy, and Á. Rimanóczy. 2003. Disappearance of ethanol from isolated sheep rumen. Acta Vet. Hung. 51:189-196.

Zammit, V. A. 1990. Ketogenesis in the liver of ruminants-Adaptations to a challenge. J. Agric. Sci. (Camb.) 115:155-162. 